\title{
Catching efficiency of multifilament trammel nets with different twisted twine for shrimp fishing in Kotabaru, Indonesia
}

\author{
Ahmadi $^{*}$ (D) Ellysabet Kristina² \\ ${ }^{1}$ Faculty of Marine and Fisheries, Lambung Mangkurat University, Indonesia, 70714 \\ ${ }^{2}$ Department of Marine and Fisheries Kotabaru District, Indonesia 72116 \\ *Corresponding author: ahmadi@unlam.ac.id
}

How to cite this paper:

Ahmadi \& Kristina, E. (2017). Catching efficiency of multifilament trammel nets with different twisted twine for shrimp fishing in Kotabaru, Indonesia. Ege Journal of Fisheries and Aquatic Sciences, 34(4):363-368. doi: 10.12714/egejfas.2017.34.4.01

\begin{abstract}
Fishing experiments were carried out in Kotabaru of Indonesia to determine catching efficiency of double-twisted and triple-twisted multifilament trammel nets. A total of 10 nets were constructed with the same dimension and inner-outer mesh sizes (40-mm and 80-mm). Trials covered 160-net hauls/type with 1-hour submersion time. The shrimps were composed of Penaeus monodon, Penaeus merguensis, Metapenalis monoserus, Penaeus semiculatus and Parapenaeopsis sculptilis. A total of $142.8 \mathrm{~kg}$ shrimp comprises $84.46 \mathrm{~kg}(59.15 \%)$ for double-twisted and $58.34 \mathrm{~kg}(40.85 \%)$ for triple-twisted were collected over 16-daytrip sampling period, indicating double-twisted multifilament trammel net was $45 \%$ more efficient. The average weight of double-twisted $(5.25 \pm 1.64 \mathrm{~kg})$ was considerably higher than that of triple-twisted $(3.65 \pm 1.41 \mathrm{~kg})$ as well as total YPUE of double-twisted $(1.056 \pm 0.02 \mathrm{~kg})$ was considerably higher than that of triple-twisted $(0.729 \pm 0.02 \mathrm{~kg})(P<0.05)$. Some recommendations for improving performances and efficiency of trammel nets are made, for example, by inserting the additional bag collector along the lower part of the nets, placing selvedge between the lead line and the net or using underwater lamps associated with the net.
\end{abstract}

Keywords: double-twisted, triple-twisted, trammel net, weight, YPUE, Kotabaru

\section{INTRODUCTION}

The development of fishing technology in Indonesia is in line with the progress of fishing science, including the knowledge of the gear efficiency and catch handling. This knowledge is essential for efficient fishing and better fisheries resource management. Pauly \& MacLean (2003) stated that transferring fishing effort from industrial fisheries to small-scale fisheries will have benefits for the socio-economy of the fisheries sector as well as for the ecosystems supporting the fisheries. However, in order for this to be realized, the level of information availability for small-scale fisheries should at least be as high as that of their industrial counterparts. Thus, the need to improve knowledge of small-scale fisheries is urgent.

Recently trammel nets are the most common type of fishing gears that are being used to collect shrimps from different habitats for both research and commercial purposes (Akyol, 2008; Metin et al., 2009; Aydin et al., 2013). Other comprehensive studies in shrimp fisheries sector are also conducted for trawls (Hannah et al., 2015, Xing et al., 2015, Wong et al., 2015; Osawa et al. 2015), liftnet (Abdussamad, 2006; Puspito \& Suherman, 2012; Puspito et al., 2015), traps (Calado \& Narciso, 2004); lighted trap (Øresland, 2007; Ahmadi, 2012; Ahmadi \& Rizani, 2013), and fyke nets (Barko and Habik, 2004; Jin et al. 2007; Zamyatina \& Semik, 2015). Trammel nets are also often used to sampling of populations both marine fishes (Hunt et al., 2012) and freshwater fishes (Balik, 2001). This is because trammel netting is widely considered to be a nonlethal capture technique (Hubert, 1996).

Dealing with catching efficiency, multifilament trammel nets caught on average two times more prawns than monofilament gill nets (Thomas et al., 2003). In trammel net fisheries, the length of net is more important than the height of net for enhancing the weight of shrimp catch, which is similar with the shrimp trawl net (Engas \& God, 1989; Dickson, 1993; Ahmadi et al. 2005; De Rezende et al. 2015).

Trammel nets were firstly introduced in Kotabaru District around 1980s in respond to the Presidential Decree No. $39 / 1980$ concerning trawl ban in Indonesia. Prohibition against trawls had an adversely impact on the shrimp exporter industries. Practically, the use of mini trawls is still allowable under the local regulation to support shrimp industries. At the same time, the like of mini trawls (e.g. cantrang, arad) are also being operated in other provinces bring all consequences. Nowadays, all things considered, the Ministry of Marine Affairs and Fisheries of the Republic of Indonesia issued the Ministerial Regulation No. 2/2015 to again prohibit fish trawl for the reason of fish resources protection from and against overfishing practices. Trammel nets-based shrimp fisheries 
presented opportunity and challenge for replacing trawls in Kotabaru and are considered as alternative environmentally friendly fishing gear. Fishing with trammel nets is on-going throughout the year regardless of the seasonal periods indicating shrimp in this region are available in great abundance. Table 1 clearly shows that the annual production of shrimp in Kotabaru increases proportionally with increasing the number of trammel nets. Thus, improving the catch efficiency of the trammel nets for shrimp fishing in Kotabaru is really necessary.

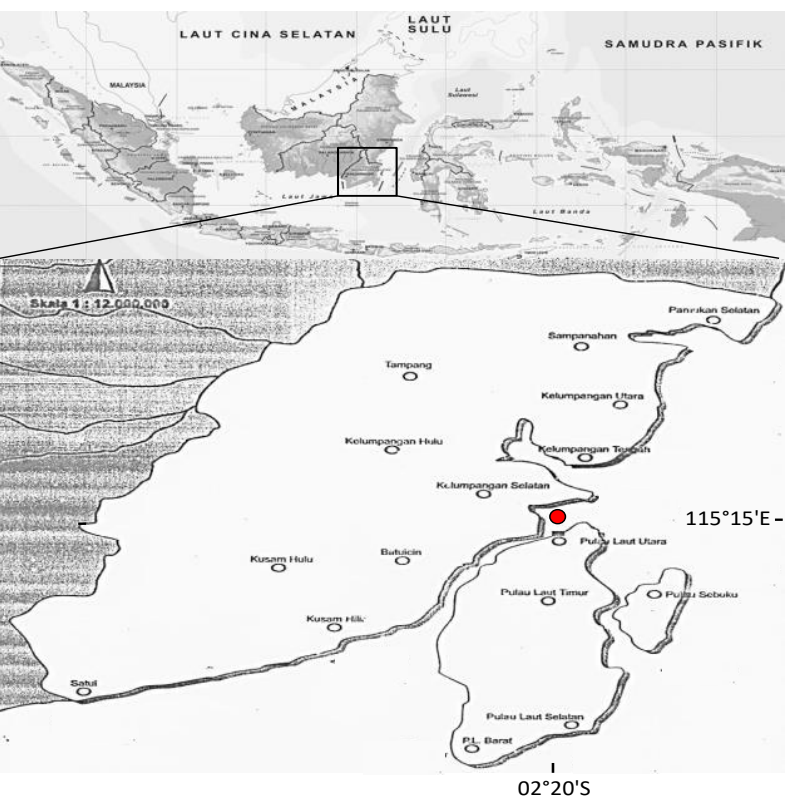

Figure 1. Map showing the location of fishing experiments in Kotabaru, South Kalimantan

There are two types of trammel net twines used in Kotabaru, namely monofilament and multifilament-nylon twines. Recently most of fishermen using multifilament tramme nets for catching shrimp. They believe that the netting twines affecting on the number of shrimp to be caught. For this reason, we conducted actual investigation on trammel nets with doubletwisted and triple-twisted multifilament net twines to compare its relative efficiency. Scientifically, catching efficiency of such trammel nets in Kotabaru is still poorly studied.

\section{MATERIALS AND METHODS}

The field experiments were carried out in Kotabaru waters located at $02^{\circ} 20^{\prime} S$ and $115^{\circ} 15^{\prime} E$ (Figure 1). In the present study, a total of 10 trammel nets consisted of 5 double-twisted and 5 triple-twisted multifilament nylons were simultaneously tested for collecting shrimp species from the sea at 12-13.5-m deep. Such treatments give equal chance of success for both nets in terms of catching efficiency. Each type was constructed with two outer walls of $80-\mathrm{mm}$ PA multifilament nylon and one inner wall of $40-\mathrm{mm}$ PA multifilament nylon. The twine diameters of outer and inner walls are $110 \mathrm{D} / 9$ and $210 \mathrm{D} / 3$ respectively. Individual nets had 30-m long and 2-m deep with hanging ratios of $E=0.50$ for outer wall and $E=0.45$ for inner wall. Each net attached to the head rope and foot rope $32 \mathrm{~m}$ long, $\varnothing 2 \mathrm{~mm}$. The float made of foam, circle-shape, 74 pcs; while the sinker made of lead, oval-shape, 74 pcs plus extra 5 $\mathrm{kg}$ weigh of cast-cement on otter board.

Table 1. The trend status of shrimp fishing in Kotabaru District during 2011-2015

\begin{tabular}{ccccccc}
\hline No & Variables & \multicolumn{5}{c}{ Year } \\
\cline { 2 - 6 } & 2011 & 2012 & 2013 & 2014 & 2015 \\
\hline 1. & $\begin{array}{l}\text { Annual } \\
\text { production } \\
\text { (ton) }\end{array}$ & 192.94 & 337.64 & 590.87 & 709.04 & 4,930 \\
2. & $\begin{array}{l}\text { Capture fishery } \\
\text { households }\end{array}$ & 5,492 & 5,495 & 5,945 & 4,591 & 9,393 \\
3. & $\begin{array}{l}\text { Fishing boats } \\
\text { (<5 GT) } \\
\text { 4. }\end{array}$ & 4,966 & 4,970 & 4,790 & 3,892 & 6,749 \\
\hline & $\begin{array}{l}\text { Number of } \\
\text { trammel nets }\end{array}$ & 1,618 & 2,962 & 3,368 & 3,668 & 3,778 \\
\hline
\end{tabular}

On each sampling date, ten replicates were arranged randomly with the same method and deployed in different locations following day using outboard wooden motor boat (6.5$\mathrm{m}$ long, 1.5-m wide, 1.5-m high, engine of Tianli Domping 20, China). The fishing spots were about 2-mile from coastal line and the nets left at the bottom sea for about 1-hour. All fishing operations were conducted in the morning and supported by professional fishers. The trials consisted of 160-net hauls/gear type with 1-hour submersion time. Both net types were standardized to a yield per unit effort (YPUE) of total catch $(\mathrm{kg})$ per 16-daytrip. On landing site, the catches were removed separately from each net and then identified for species and measured for weight to determine and compare the YPUEs of trammel net types. The YPUE was calculated using the following equation (Godoy et al., 2003), which is adapted for this study:

$$
Y P U E=\frac{\sum \text { weight }}{\sum \text { number of nets } * \sum \text { fishing trials }}
$$

The daily total and average of all catches are stated in mean \pm standard deviation. The weight data analyzed met the assumptions of Lilliefors normality test. The t-test was used to examine whether or not significant difference occurred between the catch weight of individual nets in the same type or that of two trammel nets types tested. All statistical analyses were considered significant at $5 \% \quad(P<0.05)$ using SPSS-16.0 software.

\section{RESULTS}

A total of $142.80 \mathrm{~kg}$ shrimp comprises $84.46 \mathrm{~kg}$ (59.15\%) for double-twisted multifilament trammel nets and $58.34 \mathrm{~kg}$ $(40.85 \%)$ for triple-twisted were collected over 16-daytrip sampling periods as shown in Table 2 . The daily total and average of all catches were also recorded as $8.93 \mathrm{~kg}$ and 4.44 $\mathrm{kg}$ respectively. The average weight of 160-net hauls/gear type of shrimp captured by double-twisted and triple-twisted 
multifilament nets was $5.28 \pm 1.64 \mathrm{~kg}$ and $3.65 \pm 1.41 \mathrm{~kg}$. There was statistically significant difference in the percentage of daily average weight between double-twisted and triple-twisted multifilament nets $(\mathrm{t}=5.530, \mathrm{df}=30, P<0.01)$. The percentage of daily average weight for double-twisted ranged from 35.31 to
$78.30 \%$ and from 21.70 to $64.69 \%$ for triple-twisted multifilament.

The total weight of the captured shrimp was 1.45 times higher for double-twisted multifilament nets than triple-twisted ones ( $\mathrm{t}=3.022, \mathrm{df}=30, P<0.05)$.

Table 2. The descriptive comparison of caught shrimp $(\mathrm{kg})$ between double-twisted (DT) and triple-twisted (TT) multifilament trammel nets over 16-day sampling periods. (YPUE = Yield per Unit Effort)

\begin{tabular}{|c|c|c|c|c|c|c|}
\hline Number of Trial & $\begin{array}{c}\text { Double-twisted } \\
\text { multifilament }\end{array}$ & $\begin{array}{l}\text { Triple-twisted } \\
\text { multifilament }\end{array}$ & $\begin{array}{l}\text { Daily all } \\
\text { catches }\end{array}$ & $\begin{array}{l}\text { Daily average } \\
\text { of all catches }\end{array}$ & DT : TT & $P$ \\
\hline 1 & 2.6 & 1.48 & 4.08 & 2.04 & $1.76: 1$ & $P>0.05$ \\
\hline 2 & 4.02 & 2.44 & 6.46 & 3.23 & $1.65: 1$ & $P<0.01$ \\
\hline 3 & 3.27 & 2.66 & 5.93 & 2.97 & $1.23: 1$ & $P>0.05$ \\
\hline 4 & 5.1 & 4.72 & 9.82 & 4.91 & $1.08: 1$ & $P>0.05$ \\
\hline 5 & 6 & 6.65 & 12.65 & 6.33 & $0.90: 1$ & $P>0.05$ \\
\hline 6 & 3.45 & 6.32 & 9.77 & 4.89 & $0.55: 1$ & $P<0.01$ \\
\hline 7 & 7 & 1.94 & 8.94 & 4.47 & $3.61: 1$ & $P<0.01$ \\
\hline 8 & 4.3 & 3.06 & 7.36 & 3.68 & $1.41: 1$ & $P>0.05$ \\
\hline 9 & 5.25 & 3.99 & 9.24 & 4.62 & $1.32: 1$ & $P>0.05$ \\
\hline 10 & 8 & 3.7 & 11.7 & 5.85 & $2.16: 1$ & $P<0.05$ \\
\hline 11 & 5.75 & 3.26 & 9.01 & 4.51 & $1.76: 1$ & $P<0.01$ \\
\hline 12 & 7.25 & 4.06 & 11.31 & 5.66 & $1.79: 1$ & $P<0.01$ \\
\hline 13 & 3.42 & 2.66 & 6.08 & 3.04 & $1.29: 1$ & $P>0.05$ \\
\hline 14 & 7.3 & 4.15 & 11.45 & 5.73 & $1.76: 1$ & $P<0.05$ \\
\hline 15 & 6 & 3.26 & 9.26 & 4.63 & $1.84: 1$ & $P<0.05$ \\
\hline 16 & 5.75 & 3.99 & 9.74 & 4.47 & $1.44: 1$ & $P<0.01$ \\
\hline Total $(\mathrm{kg})$ & 84.46 & 58.34 & 142.8 & 71.4 & $1.45: 1$ & $P<0.05$ \\
\hline Average (kg) & 5.28 & 3.65 & 8.93 & 4.44 & $1.45: 1$ & $P<0.01$ \\
\hline YPUE (kg) & 1.056 & 0.729 & 0.893 & 0.888 & $1.45: 1$ & $P<0.05$ \\
\hline
\end{tabular}

Dealing with the ratio of all catches, the double-twisted was considerably higher than triple-twisted across all trials $(P<0.05)$, except for the fifth- and sixth-trial (see Table 2). There was significantly difference in the YPUE rate between doubletwisted and triple-twisted multifilament $(t=3.041, d f=30$, $P<0.05)$. The total YPUEs gained for double-twisted and tripletwisted multifilament nets were $1.056 \pm 0.02 \mathrm{~kg}$ and $0.729 \pm 0.02$ $\mathrm{kg}$ respectively. In addition, it was also clearly visible in the ratio of daily average YPUEs to the mesh size of inner wall where double-twisted was significantly higher than triple-twisted $(\mathrm{t}=3.023, \mathrm{df}=30, P<0.05)$ as plotted in Figure 2.

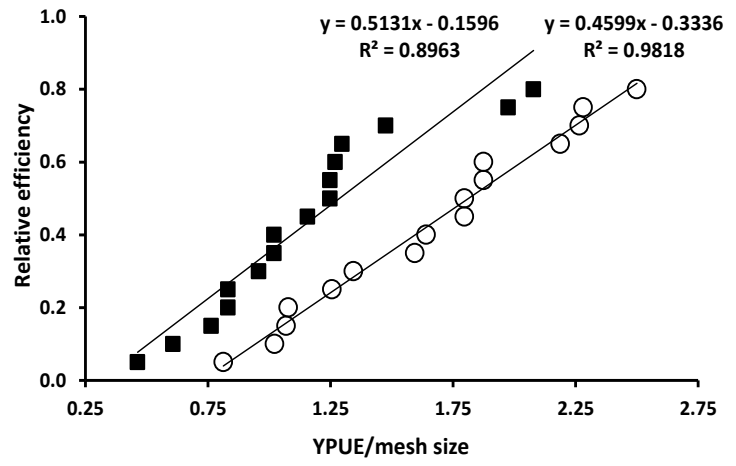

Figure 2. The relationship between relative efficiency and the ratio of daily average YPUE to mesh size $(40-\mathrm{mm})$ of double-twisted $(\bigcirc)$ and triple-twisted $(\square)$ multifilament trammel nets
The relationships between the relative efficiency and the ratio of YPUEs to mesh size of double-twisted and triple-twisted were expressed in the following linear equations: $y=0.4599 x$ $0.3336\left(R^{2}=0.9818\right)$ and $y=0.5131 x-0.1596\left(R^{2}=0.8963\right)$, respectively. Figure 3 shows the daily total weight of both typical nets and percentage of daily YPUE gained over 16daytip periods. The data points of daily total weight spread on the figure didn't seem to be linear $\left(R^{2}=0.1825\right)$ and implied that the abundance of shrimp is different from one to other fishing spots. Meanwhile the data points of percentage of daily YPUE seem definite linear regression $\left(R^{2}=1\right)$, which meant that the proportion of weight of double-twisted was considerably higher than triple-twisted. It was determined in this study that the effect of double-twisted multifilament net twine on efficiency of trammel nets was found to be $45 \%$ more efficient than tripletwisted multifilament net twine for catching shrimp in this region. The weight of shrimp catch between individual nets within the same type of trammel nets were not found statistically different $(P>0.05)$.

The catches composition included tiger prawn (Penaeus monodon Fabricius, 1798), white shrimp (Penaeus merguensis De Man, 1888), brown shrimp (Metapenalis monoserus Fabricius, 1798), green tiger prawn (Penaeus semiculatus de Haan, 1844), and rainbow shrimp (Parapenaeopsis sculptilis Heller, 1862). All shrimp species are readily available 
market particularly for shrimp processing industries in Kotabaru as shrimp frozen export products.

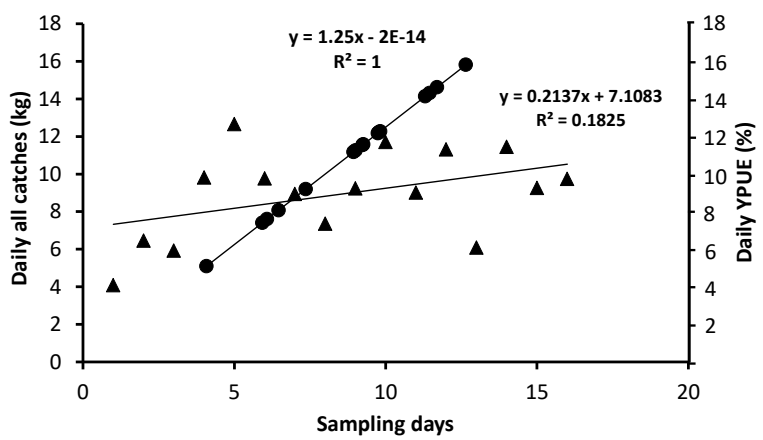

Figure 3. The daily all catches of double-twisted and triple-twisted multifilament trammel nets $(\mathbf{A})$ and percentage of daily YPUE $(\mathbf{O})$ of double-twisted over triple-twisted during 16-daytrip periods

\section{DISCUSSION}

The catching efficiency of trammel nets is much influenced by the twine materials, the colour of material, mesh size, hanging ratio, tension acting on the net due to buoyancy of floats, visibility of netting, change in the shape of netting by the current and others (Klust, 1982; Koike \& Matuda, 1988). The twine material should be carefully chosen in order to have a flexibility of netting structure, high breaking strength, lesser visibility, softness, and knot strength. However, there is no ideal material having all the desired properties, and therefore, the selection of the best available material for a specific purpose is important.

In the present study, double-twisted multifilament trammel net is $45 \%$ more efficient than triple-twisted due to the higher elasticity and flexibility of the thinner twine. It is practically accepted that the diameter and material of twine can influence visibility, elasticity and flexibility of both gillnet and trammel net (Balık \& Çubuk, 2000; Holst et al., 2002). Typically, monofilament is more elastic and more efficient than multifilament due to smaller twine diameter (Karlsen \& Bjarnason, 1986, Ayaz et al., 2011) and is less visible (Backiel \& Welcomme, 1980; Radhalakshmi \& Gopalan Nayar, 1985) explaining the primary differences in efficiency between these twine materials. Thus, the catching efficiency of monofilament trammel nets is higher than multifilament for catching fish species (Wudianto et al., 1988; Balik, 2001). Meanwhile Matsuoka (1995) explained that the catch ability of the multifilament nylon was better than the monofilament nylon for gilled capture of croaker species. Thus, information on the catching efficiency of trammel nets is inconsistent, which is depending on the targeted species, net webbing, selectivity mechanism or experimental conditions.

In our observation, trammel net fishing with double-twisted multifilament seemed to be more suitable for keeping the catch shrimp with intact condition. Despite many benefits of using double-twisted multifilament, they may not be appropriate in all situations. This typical net has also limitations like all sampling devices. It was less durable and not repairable. Fishermen said that the use of such net only for about one month, while another prevail up to three months. Therefore, it is a great challenge for the local netting factory to produce multi-monofilament with high breaking strength, more elastic and more durable. According to Hovgard \& Lassen (2000), nylon multimonofilament is made of a number of monofilament nylon thread or monofilaments in parallel. Multi-monofilament nets are generally considered the most efficient as the use of thin parallel threads make the net softer than monofilament or multifilament. It makes multi-monofilament nets more flexible underwater. Such type of net can be recently seen in the millennium gillnet fisheries (Rakhmadevi et al., 2008).

The size and type of trammel nets used in the present study are the same as those used by local fishermen. The inner panel mesh size of $40-\mathrm{mm}$ of both net types is considered suitable for catching shrimp species in Kotabaru waters. Such mesh size is slightly larger than minimum mesh size regulation of $38-\mathrm{mm}$. We observed that the outer panel mesh size $(80-\mathrm{mm})$ used in the trials did not significantly affect the catch characteristics in terms of catch weight and species composition as well as the size selectivity of the trammel nets. Its function is more or less as a temporary 'bag' when shrimp entangled in the net. Fujimori et al. (1996) observed the fishing mechanism on how kuruma prawn (Penaeus japonicus) becomes entangled in a trammel net with monofilament nylon in a small water tank. First, the prawn slowly crawls forward and approaches the edge of the trammel net. On contact with the inner and/or outer part of the net, the prawn jumped backwards to avoid the net. However, if in this process the rostrum or appendages entangles, then the prawn on further struggling tangles with the mesh and is caught. The probability that an appendage of the prawn touches and entangles with the net is assumed to be related to the body length and the mesh size.

Selectivity analysis is not performed in this study since both typical nets had the same mesh size $(40-\mathrm{mm})$, and therefore a comparison within a mesh size is not possible. To the best knowledge of the authors, there is no study on the selectivity properties of trammel nets for shrimp fisheries in Kotabaru, so far. For this reason, we intend to conduct a series of the trammel net fishing with different mesh sizes. The observation includes the age class group corresponding to the mesh sizes as well as determination of allometric growth pattern and condition factor of shrimp. Practically trammel net or gillnet with the same nominal mesh sizes but different twine thicknesses will possibly result in different mesh openings during the fishing operation. Ayaz et al. (2011) investigated the effect of twine thickness on the selectivity of multifilament gillnet when targeting Bogue (Boops boops $\mathrm{L}$ ), and found that the $22 \mathrm{~mm}$ mesh size net $(0.45 \mathrm{~mm} \varnothing)$ captured significantly larger fish than the $23 \mathrm{~mm}$ mesh size net $(0.54 \mathrm{~mm} \varnothing)$, due to the higher elasticity and flexibility of the thinner twine. Park et al. (2011) 
found that the size selectivity of the trammel net and gillnet was significantly different with only $0.2 \mathrm{~cm}$ difference in the modal length.

Among technical problem beyond our observation is that we cannot precisely estimate the amount of shrimp get out of the nets (after being caught) and then fall to the seabed particularly when the nets are being lifted on board. For this reason we plan to attach the additional net as 'bag collector' along the lower part of trammel nets to accommodate shrimps that released from the nets. By doing this, the catch ratio between shrimp entangled in the net and shrimp dropped into the 'bag collector' is comparable. This includes investigation of the effect of soaking time in such trammel net at different depth of the sea, and the results are still open for discussion. Placing selvedge between the lead line and the net is also good option to reduce discards. Metin et al. (2009) used selvedge to decrease discards of crustaceans and gastropods in prawn (Melicertus kerathurus) trammel nets in Izmir Bay of Turkey, and successfully reduced discards by $40 \%$. More site-specific studies for testing trammel net models would be required to determine the optimum fishing levels that would satisfy fisheries and nature conservation interests in Kotabaru. Innovation in this fishery can also be served through the use of LED underwater lamps associated with trammel net during nighttime produces many predictable results. This is a great challenge for us (Ahmadi, 2012) since there are no reports on the phototactic response in shrimp and its application in Kotabaru, so far. It is also greatly possible to increase the efficiency of trammel net by changing the way of catching from passive to active method, where the trammel nets (with various mesh sizes or different webbing materials) towed encircling and swept over the sea

\section{REFERENCES}

Abdussamad, E.M. (2006). Ingression, abundance and settlement dynamics of Penaeid shrimp postlarvae in backwaters and adjacent tidal ponds in Cochin, India. Bangladesh Fisheries Research, 10(2):151-158.

Ahmadi, Fuwa, S., Ebata, K. \& Budiman, J. (2005). Comparative study on the performance of Lampara Dasar (Indonesia traditional bottom trawls). Member of Faculty Fishery Kagoshima University, 54:45-56.

Ahmadi. (2012). Catch efficiency of low-powered incandescent light and LED light traps fishing in Barito River of Indonesia. Kasetsart University, Fisheries Research Bulletin, 36(3):1-15.

Ahmadi \& Rizani, A. (2013). Light traps fishing in Sungai Sipai flood swamp of Indonesia: Recommendations for future study. Kasetsart University Fisheries Research Bulletin, 37(2), 17-30.

Akyol, O. (2008). Fish by-catch species from coastal small-scale shrimp trammel net fishery in the Aegean Sea (Izmir Bay, Turkey). Journal of Applied Ichthyology, 24(3):339-341. doi: 10.1111/j.1439-0426.2008.01066.x

Ayaz, A., Altinagac, U., Ozekinci, U., Ozen, O., Altin, A. \& Ismen, A. (2011) Effect of twine thickness on selectivity of gillnets for bogue, Boops boops, in Turkish waters. Mediterranean Marine Science, 12(2):358-368. doi: $10.12681 / \mathrm{mms} .37$

Aydin, I., Gokce, G. \& Metin, C. (2013). Using guarding net to reduce regularly discarded invertebrates in trammel net fisheries operating on seagrass meadows (Posidonia oceanica) in İzmir Bay (Eastern Aegean Sea). Mediterranean Marine Science, 14(2):282-291. doi: 10.12681/mms.425 bottom of fishing ground. In Banten of West Java, the sweeping method had been proved to have a better catch than the passive method (Wudianto, 1985), while in Kotabaru, it has not been reported. In doing so, more detailed data are needed to analyze the factors leading to these variations. For better fisheries management, the development of the trammel net fishery must not only be addressed to increase its productivity but also directed to improve its selectivity performance as well as to reduce the bycatch (non-targeted species).

\section{CONCLUSION}

The present study clearly demonstrates that trammel nets fishing with double-twisted multifilament net twine was $45 \%$ more efficient than triple-twisted multifilament net. This is because double-twisted multifilament net is softer and more flexible resulting in the catches is entangled. The twisting reduces the elasticity of triple-twisted multifilament. The YPUE gained for double-twisted was considerably higher than tripletwisted multifilament nets. The use of double-twisted multifilament trammel net will create more economic fishing activity for the local fishermen in supporting shrimp processing industry in Kotabaru, but it should be controlled regularly by the local authority to make sure over-fishing is not happened.

\section{ACKNOWLEDGEMENTS}

The author is grateful to Mr. Muhammad Rizky Masmahardie for their valuable time during the research. Thanks are also due to the skipper and his crew for their cooperation during fishing experiments. The authors also wish to acknowledge the constructive criticism of anonymous reviewers.

Backiel, T. \& Welcomme, R. L. (1980). Guidelines for Sampling Fish in Inland Waters. FAO, EIFAC Technical Paper No. 33, 53 p.

Balik, I. \& Çubuk, H. (2000). Efficiency of capture of tench, Tinca tinca L. by trammel nets of monofilament and multifilament net twine combinations. Fisheries Management and Ecology, 7(6):515-521. doi: 10.1046/j.1365-2400.2000.00216.x

Balik, I. (2001). Comparison of Seasonal Catch Per Unit Efforts for Mono- and Multifilament Trammel Nets in Lake Beyehir. Turkish Journal of Fisheries and Aquatic Science, 1, 17-21.

Barko, V.A. \& Hrabik, R.A. (2004). Abundance of Ohio Shrimp (Macrobrachium ohione) and Glass Shrimp (Palaemonetes kadiakensis) in the Unimpounded Upper Mississippi River. American Midland Naturalist, 151(2):265-273.

doi: 10.1674/0003-0031(2004)151[0265:AOOSMO]2.0.CO;2

Calado, R. \& Narciso, L. (2004). An inexpensive baited trap for collecting cryptic decapod crustaceans. Crustaceana, 77(3):341-351. doi: $10.1163 / 1568540041181510$

Dickson, W. (1993). Estimation of the capture efficiency of trawl gear. II: Testing a theoretical model. Fisheries Research, 16(3):255-272. doi: 10.1016/0165-7836(93)90097-Q

De Rezende, G. A., Neunfeld, A. L., Estima, S. C. \& Dumont, L. F. C. (2015) Size structure of the pink shrimp, Farfantepenaeus paulensis (PérezFarfante, 1967) (Decapoda: Penaeoidea), in a subtropical estuary: an 
assessment motivated by demand from fishermen. Pan-American Journal of Aquatic Science, 10(2):105-115

Engas, A. \& God, O. R. (1989). The effect of different sweeps on length composition of bottom sampling trawl catches. Journal du Conseil / Conseil Permanent International pour l'Exploration de la Mer, 45:263-268. doi: 10.1093/icesjms/45.3.263

Fujimori, Y., Tokai, T., Hiyama, S. \& Matuda, K. (1996). Selectivity and gear efficiency of trammel nets for kuruma prawn (Penaeus japonicas). Fisheries Research, 26:113-120. doi: 10.1016/0165-7836(95)00392-4

Godøy, H., Furevik, D. \& Lokkeborg, S. (2003). Reduced by catch of red king crab (Paralithodes camtschaticus) in the gillnet fishery for cod (Gadus morhua) in northern Norway. Fisheries Research, 62:337-384. doi: $10.1016 / \mathrm{S} 0165-7836(02) 00281-3$

Hannah, R.W., Lomeli, M.J.M. \& Jones, S.A. (2015). Tests of artificial light for bycatch reduction in an ocean shrimp (Pandalus jordani) trawl: strong but opposite effects at the footrope and near the bycatch reduction device. Fisheries Research, 170:60-67. doi: 10.1016/j.fishres.2015.05.010

Holst, R., Wileman, D. \& Madsen, N. (2002). The effects of twine thickness on the size selectivity and fishing power of Baltic cod gill nets. Fisheries Research, 56(3):303-312. doi: 10.1016/S0165-7836(01)00328-9

Hovgard, H. \& Lassen, H. (2000). Manual estimation of selectivity for gill net and longline gears in abundance surveys. FAO Fisheries Technical Paper. No. 397, $84 \mathrm{p}$

Hubert, W.A. (1996). Passive capture techniques. In B.R. Murphy and D.W. Willis (eds), Fisheries techniques (pp.157-192), Second edition. American Fisheries Society Bethesda, MD.

Hunt, T.A., Ward, D.L., Propper, C.R. \& Gibb, A.C. (2012). Effects of Capture by Trammel Net on Colorado River Native Fishes. Journal of Fish and Wildlife Management, 3(1):133-141. doi: 10.3996/122011-JFWM-070

Jin, B.S., Fu, C.Z., Zhong, J.S., Chen, J.K. \& Wu, J.H. (2007). Effect of Fyke net mesh size and sampling period on the catch of nekton in an intertidal creek. Acta Hydriblogica Sinica, 31:39-44

Karlsen, L. \& Bjarnason, B.A (1986). Small-scale Fishing with Driftnets. FAO Fisheries Technical Paper No: 284, 64 p.

Klust, G. (1982). Netting Materials for Fishing Gear. Second edition, FAO,175p.

Koike, M. \& Matuda, K. (1988). Catching efficiency of a trammel net with different vertical slackness and mesh size of inner net. In World Symposium: on Fishing Gear and Fishing Vessel Design (pp. 468-472). Canada: Marine Institute St. John's Newfoundland. Proceeding Book.

Matsuoka, T. (1995). Selectivity of fishing gear and its application for sustainable development of fisheries. Kagoshima University, Japan. 31 p.

Metin, C., Gokce, G., Aydin, I. \& Bayramic, I. (2009). Bycatch reduction in trammel net fishery for prawn (Melicertus kerathurus) by using guarding net in İzmir Bay on Aegean Coast of Turkey. Turkish Journal of Fisheries and Aquatic Science, 9:133-136.
Øresland, V. (2007). Description of the IMR standard light trap and the vertical distribution of some decapod larvae (Homarus and Nephrops). Western Indian Journal of Marine Science, 6:225-231.

Osawa, Y., Aoki, M.N., Bauer, R.T. \& Thiel, M. (2015). Numbers and sizes of the shrimp Rhynchocinetes uritai Kubo, 1942 (Decapoda: Caridea) caught in bait and refuge traps. Journal of Crustacean Biology, 35(6):768-775. doi: $10.1163 / 1937240 X-00002374$

Park, H.H., Millar, R.B., Bae, B.S., An, H.C., Chun, Y.Y., Yang, J.H. \& Yoon, S.C. (2011). Size selectivity of Korean flounder (Glyptocephalus stelleri) by gillnets and trammel nets using an extension of SELECT for experiments with differing mesh sizes. Fisheries Research, 107:196-200. doi: 10.1016/j.fishres.2010.10.020

Pauly, D. \& MacLean, J. (2003). In a Perfect Ocean - The State of Fisheries and Ecosystems in the North Atlantic Ocean. Island Press, Washington, $175 \mathrm{p}$.

Puspito, G. \& Suherman, A. (2012). Effectiveness of Fluorescent Lamp on Lift Net Fishery. Journal of Applied Science Research, 8(9):4828-4836.

Puspito, G., Thenu, I. M., Julian, D., \& Tallo, I. (2015). Utilization of light-emitting diode lamp on lift net Fishery. AACL Bioflux, 8(2):159-167.

Rakhmadevi, C.C., Purbayanto, A. \& Sondita, M.F.A. (2008). Studies on Capture Process and Fish Behaviour towards Millennium Gill Net in Bondet Waters, Cirebon. Indonesian Fisheries Research Journal, 14:1-6. doi: 10.15578/ifrj.14.1.2008.1-6

Thomas, S.N., Edwin, L. \& George, V.C. (2003). Catching efficiency of gill nets and trammel nets for penaeid prawns. Fisheries Research, 60(1):141-150 doi: 10.1016/S0165-7836(02)00057-7

Wong, B.Y., Ong, H.K.A. \& Khoo, G. (2015). Length-Weight Relationships of Acetes spp. sampled along the West Coast of Peninsular Malaysia. Sains Malaysiana, 44:379-386. doi: 10.17576/jsm-2015-4403-09

Wudianto. (1985). An Experiment on the Operation Method of Pocket Net (Jaring Kantong) in Banten water. Marine Fisheries Research Journal, No. 33. Jakarta: Marine Fisheries Research Institute.

Wudianto, Widodo, A.P.A \& Nasution, C. (1988). The Effect of the use of monofilament twine as material of trammel net to Banana shrimp catch. Marine Fisheries Research Journal, No. 48. Jakarta: Marine Fisheries Research Institute.

Xing, B., Qi, Y. \& Lin, Z. (2015). Study on cod-end mesh selectivity of beam shrimp trawl in Panjin sea area. Fishery Modernization, 42(1):57-60.

Zamyatina, E.A. \& Semik, A.M. (2015). Studies of ichthyofauna composition as by-catch in the fyke nets during the research catch of the grass shrimp (Palaemon adspersus) in the coastal areas off the Crimean Peninsula. Proceedings of the Southern Scientific Research Institute of Fisheries and Oceanography, 53:92-9. 